\title{
B ALLELE OF B-LACTOGLOBULIN AS A MARKER OF DAIRY TRAITS IN PAKISTANI GOAT BREEDS
}

\author{
G. K. Raja ${ }^{*}$, A. Mahmood, R. M. Saqlain, M. M. Zafar, A. M. Raja, P. A. Shaiq and S. M. S. Naqvi \\ University Institute of Biochemistry and Biotechnology, Pir Mehr Ali Shah Arid Agriculture University, Murree Road, \\ Rawalpindi, Pakistan \\ *Corresponding Author's E-mail: ghazala@uaar.edu.pk \\ https://doi.org/10.36899/JAPS.2020.1.0002 \\ Published online January 02, 2020
}

\begin{abstract}
Genetic isoforms of $\beta$-Lactoglobulin (BLG) gene in dairy animals are reported to affect major milk production traits. Present study was planned to identify BLG genotypes in two local goat breeds, Beetal and Daera Din Panah (DDP), to explore their associations with major milk constituents and daily milk yield. Milk and blood samples were collected from animals reared in government livestock farms and privately managed animal herds during December 2010 to January 2012 and further analyzed in Animal Biotechnology laboratory (ABL), University Institute of Biochemistry and Biotechnology (UIBB), Pir Mehr Ali Shah Arid Agriculture University Rawalpindi (PMAS-AAUR). Animals were genotyped for BLG locus using PCR-RFLP method. Quantification of milk proteins and total milk fat contents were carried out using Bradford method and Gerber method respectively. BLG genotype and allele frequencies were computed and tested for associations with major milk constituents and daily milk yield. The genotype frequencies in Beetal goats were; AA: 0.28, AB: 0.55, BB: 0.18 and in DDP goats were; AA: 0.31 , AB: 0.53 and BB: 0.15 . There was an abundance of heterozygous $\mathrm{AB}$ genotype with significantly high frequency of $\mathrm{A}$ allele in both animals (Beetal 0.55 and DDP 0.58). The heterozygous AB and homozygous $\mathrm{BB}$ genotyped Beetal goats had higher total milk protein (2.64 \pm 0.855 and $2.56 \pm 0.98 \%, \mathrm{p}=0.03)$ and casein protein $(2.25 \pm 0.71 \%$ and $2.19 \pm 0.81 \%, \mathrm{p}=0.04)$ contents compared to homozygous AA genotype. The B allele significantly associated with higher whey protein contents in Beetal goats $(\mathrm{OR}=4.8, \mathrm{CI}=1.06-21.62)$ and total milk fat contents in DDP goats $(\mathrm{OR}=1.91, \mathrm{CI}=1.04-3.51)$. Overall we report high frequency of BLG AB genotype and A allele in Beetal and DDP goat breeds. However B allele proved to be a good marker of dairy traits in Beetal and DDP goat breeds due to its significant association with higher whey protein and total milk fat contents.
\end{abstract}

Key words: Milk Proteins, Whey, Polymorphism, $\beta$-Lactoglobulin.

\section{INTRODUCTION}

Dairy animals are a rich source of pure dietary proteins most abundantly caseins and whey in the form of milk (Cardona et al., 2016). Caseins and whey major milk proteins which exist in various polymorphic forms at both gene and protein levels in different animal populations (Ballester et al., 2005). Among whey proteins, $\beta$-Lactoglobulin (BLG) is an abundant protein in ruminant milk largely associated with milk quality as well as quantity (Ruprichová et al., 2014). The protein consisting 162 amino acids (Preaux et al., 1979) is encoded by BLG gene, mapped on chromosome 11, containing 7 exons (Folch et al., 1994). Polymorphism in BLG protein was first discovered by Aschaffenburg in bovine milk (1955) since then BLG variants at both protein and gene levels have been reported in different dairy animals including goats (Othman et al., 2012). While twelve genetic bovine BLG variants have been discovered, only two, A and B, have been reported to be abundantly present in goats (Medrano and
Aguilar-Cordova, 1990; Pena et al., 2000). The two BLG alleles, A and B, are the result of a point mutation ( $G$ to A) at +4601 position in exon 7 (Pena et al., 2000). Due to the world-wide acceptance of bovine milk and its dairy products, goat milk has long stayed a rather neglected research area. However, goat milk and its dairy products are now gaining huge acceptance in the world food market due to their unique nutritional and physiological properties (Selvaggi et al., 2014). Developed countries are investing into the scientific research exploiting polymorphisms in goat milk protein encoding genes and their effect on the biochemical and technological properties of milk and dairy products (Barillet, 2007). Pakistan has a rich genetic pool in terms of goats with around 37 breeds reared in specific geographical regions. Though usually carried out on small scale in rural areas, goat farming in Pakistan is mainly practiced for meat production with no genuine demand for raw milk or dairy products. Overall the dairy potential of goats has remained a rather neglected area in Pakistan that is in dire need to be explored scientifically. Keeping in view the 
importance of milk protein encoding genes as dairy markers, present study was designed to identify genetic variants of BLG gene in two important milk producing local goat breeds, Beetal and DDP and their association with daily milk yield and contents of important milk constituents. Both goats are reared in the Punjab province of Pakistan and are amongst excellent ruminant genetic herds. The identified BLG isoforms and their genetic association analysis will highlight their role as a marker of the biochemical properties of raw milk. While in a longer run, current research could be a starting point for studies focused at dairy product manufacture aimed at specified technological properties for use in dairy industry.

\section{MATERIALS AND METHODS}

Data Collection and Sampling: A total of 400 animals (200 Beetal and 200 DDP each), being good health and mid-lactation period, were selected for sampling. Animals were selected from government livestock farms (Kharimurat/Attock, Rakh khairy wala/Layyah, Rakh Ghulaman/Bhakkar) and privately managed animal herds (Jaman Shah, Kot Sultan, and Pahar Pur Thal, Layyah) located in Punjab, Pakistan. The time period for samples collection was spread on December 2010-January 2011, March 2011, August-September 2011 and December 2011-January 2012. Approximately $50 \mathrm{~mL}$ of fresh milk samples were collected in sterilized Falcon tubes during morning milking session from animals. Total milk yield was recorded as Liters per day (L/Day). For genotyping, $4-5 \mathrm{~mL}$ blood samples were collected from jugular vein using $5 \mathrm{~mL}$ disposable, sterilized syringes in EDTA vacutainers. The milk and blood samples were kept on ice in cold boxes during transportation and stored at $4^{\circ} \mathrm{C}$ till further processing. All laboratory experiments were carried out in ABL situated in UIBB, PMAS-AAUR, Rawalpindi, Pakistan.

Processing and Analysis of Milk Samples: For analysis, a $20 \mathrm{~mL}$ aliquot of whole milk was skimmed by centrifuging at $664 \mathrm{~g}$ for 30 minutes (at room temperature) and refrigerated to solidify the and remove the upper fat layer. Skimmed milk was stored at $-20^{\circ} \mathrm{C}$ for further analysis. The whey milk fraction was separated using acid precipitation of casein proteins at their isoelectric point $\mathrm{pH} 4.5$ (Yeang et al., 1998) and stored at $-20^{\circ} \mathrm{C}$ till further analysis. Total milk protein and whey protein contents were estimated using Bradford method (Bradford, 1976). For caseins protein quantification, whey protein contents were subtracted from total milk proteins. For the quantification of total milk fat contents Gerber method was used (Kleyn et al., 2001). All milk constituents (Total protein, whey, caseins and total fat) were presented as percentage $(\%)$.
PCR-RFLP Based BLG Genotyping: Genomic DNA was extracted from whole blood using standard organic solvent precipitation method (Sambrook and Russell, 2001). The quantification of extracted genomic DNA stocks and their purity were checked using nanodrop spectrophotometer at $260 \mathrm{~nm} / 280 \mathrm{~nm}$ and further confirmed on $1 \%$ agarose gel.

For PCR amplification primers already described by (Folch et al., 1994), spanning exon 7 and 3'UTR region of BLG gene, were used;

Forward: 5'-CGGGAGCCTTGGCCCTCTGG-3'

Reverse: 5'-CCTTTGTCGAGTTTGGGTGT-3'

A $15 \mu \mathrm{L}$ PCR reaction mixture was set up containing: $50 \mathrm{ng}$ genomic DNA, dNTPs each at $0.5 \mathrm{mM}$, $1.5 \mu \mathrm{L}$ of $10 \mathrm{x}$ PCR Buffer, $3 \mathrm{mM} \mathrm{MgCl} 2,0.6 \mu \mathrm{M}$ of each primer and $2.5 \mathrm{U}$ of Taq Polymerase. The cycling conditions for PCR amplification were: Initial Denaturation $95^{\circ} \mathrm{C}, 5 \mathrm{mins}$ followed by 35 cycles of: Denaturation $95^{\circ} \mathrm{C}, 30 \mathrm{secs}$; Annealing $60^{\circ} \mathrm{C}, 1 \mathrm{~min}$; Extension $\left.72^{\circ} \mathrm{C}, 1 \mathrm{~min}\right) \mathrm{x} 35$; Final extension $72^{\circ} \mathrm{C}, 5 \mathrm{~min}$. The PCR amplified products of $426 \mathrm{bp}$ size were separated on $1 \%$ Agarose gel (Figure 1).

The B allele of goat BLG gene (Substitution of $\mathrm{G}$ to A) creates a restriction site for $\mathrm{SacII}$ restriction enzyme which is missing in BLG A allele (Table 1). The PCR amplified products (426bp) were digested (in a $15 \mu \mathrm{L}$ reaction mixture) with $\mathrm{Cfr} 42 \mathrm{I}$ (SacII) (Thermo Scientific, \#ER0201) restriction enzyme (1 Unit) at $37^{\circ} \mathrm{C}$ overnight. The restriction digestion products were run on 2 percent Agarose gel along with 100bp DNA ladder (Solis BioDyne) at $80 \mathrm{~V}$ constant Voltage. Genotypes corresponding to each sample were manually counted using DNA bands separated on Agarose gel. Based on restriction digestion results the gel revealed three types of band; Homozygous AA genotype with no cut will generate a single 426bp band, homozygous BB genotype with one restriction site will generate two bands of sizes $349 \mathrm{bp}$ and $77 \mathrm{bp}$ while heterozygous $\mathrm{AB}$ genotypes will produce three bands; 426bp, 349bp and 77bp (Figure 2).

Statistical Analyses: All statistical analyses were performed Statistical Package for Social Sciences software program (SPSS v. 21.0). Descriptive statistics (Means and Standard Deviation) were performed for daily milk yield (L/Day), total milk proteins (\%), whey protein (\%), casein proteins (\%), and total fat (\%) contents. Genotype/allele frequencies were computed for each goat breed and tested for deviations from Hardy Weinberg Principle using Pearson's Chi-square $\left(\chi^{2}\right)$ Goodness of fit tests based on observed and expected genotypic frequencies. The contents of milk constituents (\%) and daily milk yield (L/Day) were compared according to three $\mathrm{BLG}$ genotypes; $\mathrm{AA}, \mathrm{AB}$ and $\mathrm{BB}$ using ANOVA. The association analysis of BLG B allele with the contents of all milk constituents and daily milk yield was carried out using logistic regression models by 
computing Odds Ratios (OR) at 95\% Confidence Intervals (CI). Significance of statistical analyses was considered with $\rho \leq 0.05$. 


\section{RESULTS}

Comparison of Milk Constituents and Milk Yield among Beetal and DDP Goats: Daily milk yield was recorded manually in morning and evening. Data was available at government livestock farms while tentative figures provided by the owners of privately raised animals. Total lactation length was 150-180 days for both breeds while high milk production lactation length was 48 weeks (Early-mid lactation phase). The average milk production data of each animal, provided by the farms/owner, was summed and mean \pm SD were calculated. Daily milk yield, total milk protein, whey protein, caseins and total fats were analyzed for any breed specific differences among Beetal and DDP goats (Table 1). Total daily milk yield was significantly higher $(\mathrm{p}=0.02)$ in DDP goat $(4.48 \pm 0.46 \mathrm{~L} / \mathrm{Day})$ as compared to the Beetal goat $(4.37 \pm 0.52 \mathrm{~L} / \mathrm{Day}) 4-8$ weeks form early to mid-lactation period. In case of milk constituents, total milk fat content was significantly higher $(p<0.001)$ in DDP goat $(4.52 \pm 0.41 \%)$ than Beetal $(4.18 \pm 0.66 \%)$ at mid lactation. The total milk protein, whey protein and casein contents lacked significant difference among both goat breeds (Table 1).

Genotype and Allele Frequencies Estimation: The PCR- RFLP genotyping results showed existence of two alleles of BLG gene; A and B with three genotypes; AA, $\mathrm{AB}$ and $\mathrm{BB}$ in our selected Beetal and DDP goat populations. In Beetal goat the frequencies of genotypes were as follows; homozygous AA 0.275 , heterozygous $\mathrm{AB} 0.545$ and homozygous $\mathrm{BB} 0.180$ respectively. The distribution of BLG genotypes in DDP goat were in the order of homozygous AA 0.312 , heterozygous AB 0.535, and homozygous BB 0.153 respectively. As presented in Table 2, the genotypes distribution in both goat populations followed Hardy Weinberg Equilibrium distribution (p-values 0.15 and 0.17 ). The frequencies of $\mathrm{A}$ and $\mathrm{B}$ allele were 0.55 and 0.45 in Beetal goat while 0.58 and 0.42 in DDP goat respectively. The frequency of A allele was significantly higher than B allele in both goat breeds (Beetal $\mathrm{p}=0.00072$ and DDP $\mathrm{p}=<0.0001$ ).

Genotypes Based Comparison of Milk Constituents and Yield: BLG genotypes based comparison of daily milk yield, total milk fat, total milk protein, whey protein and casein contents with BLG genotypes were also investigated in Beetal and DDP goats (Table 3). There was no significant difference $(p=0.288)$ in daily milk yield of both goat breeds per BLG genotypes; Beetal BLG AA 4.35 $\pm 0.44 \mathrm{~L} / \mathrm{Day}$; BLG AB 4.41 \pm 0.546 L/Day; BLG BB 4.25 $\pm 0.511 \mathrm{~L} /$ Day and DDP BLG AA 4.3 \pm 0.58 L/Day; BLG AB 4.4 \pm 0.48 L/Day; BLG BB 4.3 \pm 0.48 L/Day. Of milk constituents, total milk protein contents were significantly higher in Beetal goats having $\mathrm{AB}$ and BB genotypes $(2.64 \pm 0.855 \%$ and $2.56 \pm 0.98 \%, \mathrm{p}=0.03)$. The caseins protein contents were also were significantly raised in BLG $\mathrm{AB}$ and $\mathrm{BB}$ genotype carrier Beetal animals levels $(2.25 \pm 0.71$ and $2.19 \pm 0.81 \mathrm{p}=0.04)$ as compared to the AA genotype. The whey protein and total milk fat contents in Beetal goat milk did not show any significant difference among three BLG genotypes (Table 3). No significant difference in milk yield and milk constituents per BLG genotypes was found in DDP goats.

Association Analysis of BLG B Allele with Milk Constituents and Yield: Genetic association analysis of BLG B allele with milk constituents was also performed in Beetal and DDP goat breeds (Table 4). According to results, $B$ allele showed significant association $(p=0.041)$ with whey protein contents in Beetal goat $(\mathrm{OR}=4.8, \mathrm{CI}$ $=1.06-21.62)$ while with total milk fat contents $(\mathrm{OR}=$ $1.91, \mathrm{CI}=1.04-3.51, \mathrm{p}=0.037$ ) in DDP goat.

\section{DISCUSSION}

Results from the present study confirm that BLG locus is polymorphic in Beetal and DDP goat breeds of Pakistan with two major alleles A, B and three genotypes; $\mathrm{AA}, \mathrm{AB}$ and $\mathrm{BB}$. The genotyping results clearly indicate an abundance of heterozygous $\mathrm{AB}$ genotype and $\mathrm{A}$ allele in Beetal and DDP goats. However total milk protein and caseins contents were significantly raised in heterozygous $\mathrm{AB}$ and homozygous $\mathrm{BB}$ genotype carrier Beetal goats. The BLG B allele significantly associated with raised whey protein contents in Beetal goat and with total milk fat contents in DDP goats. Our findings highlight the importance of milk protein encoding genes based screening of dairy animals and exploration of their association with milk production traits and technological properties.

In Pakistan thirty-seven recognized goats breeds are reported with a population size of nearly 76.1 million and gross milk production is 940,000 tons (GOP, 2019). Of these only twenty breeds are reared both for milk and meat production by farmers along with private and government dairy farms. Beetal is rated as one of the most popular goat breeds in Pakistan and is reared throughout the Punjab province. The second-best goat breeds in Punjab Pakistan is DDP, reared in selected arid regions of country. On average Beetal and DDP female goats weigh $45 \mathrm{Kg}$ and $50 \mathrm{Kg}$ with a normal daily milk production of 1.3-2.7L respectively. Keeping in mind the importance of BLG gene with quantitative milk traits and technological properties of dairy products, two local dairy goat breeds, Beetal and DDP goats were screened for BLG genotypes and their association with daily milk yield and contents of milk constituents.

The A and B alleles of BLG gene are the common variants reported in most goat breeds worldwide (Kusza et al., 2015). However, the allele frequencies distribution of $\mathrm{A}$ and $\mathrm{B}$ variants vary depending upon the 
goat breeds reared in different region around the World. In present study we report an overall higher frequency BLG A allele in Beetal and DDP goat breeds as compared to the $\mathrm{B}$ allele. Of three BLG genotypes, heterozygous $\mathrm{AB}$ was more prevalent in both goat breeds followed by homozygous AA and BB genotypes. A study conducted on 13 different Indian goat breeds reported high ratio of $\mathrm{BB}$ genotype followed by $\mathrm{AB}$ (Garg et al., 2009; Kumar et al., 2006). While an abundance of AA genotype has been reported in Egyptian, French, Spanish, Colombian tropical, and Romanian (Carpatina, Banat's White, Saanen, and French Alpine) goat breeds (Cardona et al., 2016; El-Hanafy et al., 2010; Pena et al., 2000). In contrast Saudi (Ardi, Habsi, and Harri), Turkish (Hair and Saanen breeds), and Syrian goat breeds showed higher frequency of BLG B allele compared to A allele (El-Shazly et al., 2017; El Hanafy et al., 2015; Korkmaz Ağaoğlu et al., 2012) Though high diversity exists in the occurrence of particular BLG genotypes in different world caprine breeds, there seems an abundance of A allele.

Besides being abundant allele among major world goat breeds, the A allele of BLG is also shown to be associated with milk production traits (Pena et al., 2000). Therefore, an advantage of homozygous AA genotype of BLG gene has been featured in raised milk protein contents (Cardona et al., 2016) while homozygous BB genotype with significant effects on the milk fat contents. In tropical goat breeds from Colombia, BLG AA and AB genotypes had significantly higher milk protein contents in contrast to BB homozygotes (Cardona et al., 2016). The Saudi Ardi goats carrying heterozygous BLG AB genotype had higher milk fat contents while the homozygous AA BLG genotyped Syrian goats got higher total milk solids (El-Shazly et al., 2017).

However in our study, heterozygous BLG AB and homozygous BB genotype carrier Beetal goats had significantly higher total milk protein and casein protein contents as compared to the homozygous AA genotype carriers (Table 3). Though our results lacked statistical significance among BLG genotypes and all studied milk components in DDP goats, homozygous AA genotype seemed a good indicator of total milk protein, whey protein and casein contents while homozygous BB for total milk fat contents (Table 3). Furthermore the BLG A allele has also been reported for higher milk yield in goats. As for total daily milk yield, our results are in partial accordance with previous studies (Mucha et al.,
2014) Though lacking statistical significance, daily milk yield rates were raised in heterozygous $\mathrm{AB}$ genotyped Beetal and DDP goats. In Jamunapari and Barbari Indian goats, homozygous BLG AA genotype was found associated with higher milk yield as compared to heterozygous $\mathrm{AB}$ genotypes (Kumar et al., 2006). Similarly Egyptian Damascus goat breed, with highest AA genotype frequency, was reported for highest milk yield while Barki breed with low AA genotype frequency had lower milk yield (El-Hanafy et al., 2010). In, an abundance of BLG allele $\mathrm{A}$ and heterozygous $\mathrm{AB}$ genotype was observed. Likewise in Colombian tropical goat breeds, animals with BLG AA and AB genotypes gave significantly higher milk yield compared to $\mathrm{BB}$ homozygotes (Cardona et al., 2016). Saudi goats with BLG AA genotype were also reported for higher milk production rates compared to $\mathrm{AB}$ and $\mathrm{BB}$ genotype (El Hanafy et al., 2015).

Depending upon the relatively higher contents of milk constituents in $\mathrm{AB}$ and $\mathrm{BB}$ genotyped animals, association analysis of $\mathrm{B}$ allele with daily milk yield and composition was also performed. Our results clearly indicate that Beetal goat carrying BLG B allele have 4.8 times more whey protein contents as compared to those carrying A allele. Similarly BLG B allele carrier DDP goats had 1.9 times more total fat contents as compared to A allele carriers. However, an overall abundance of heterozygous $\mathrm{AB}$ genotypes in our study animals could have been influenced by the breeding practices adopted by the farmers which is performed without prior knowledge of the genetic architecture of both male and female animals used for breeding purposes. Our further studies are in progress with larger cohorts of Beetal and DDP goats to fully explore most frequent BLG allele/genotype frequency in our animal populations. In addition bucks (male animals) and goats used for breeding and progeny from selected goat farms will also be genotyped to investigate existing genetic pool and diversity. The genetic region of BLG gene harboring polymorphic site will also be sequenced in selected animals for the confirmation of allele reported in this study and existence of new/novel variants.

Overall our study revealed dominance of heterozygous $\mathrm{AB}$ genotype and BLG A allele in Beetal and DDP goat breeds of Pakistan. However, genetic association analysis strongly indicated BLG B allele as a strong dairy marker of higher whey protein contents in Beetal goats and milk fat contents in DDP goats. 


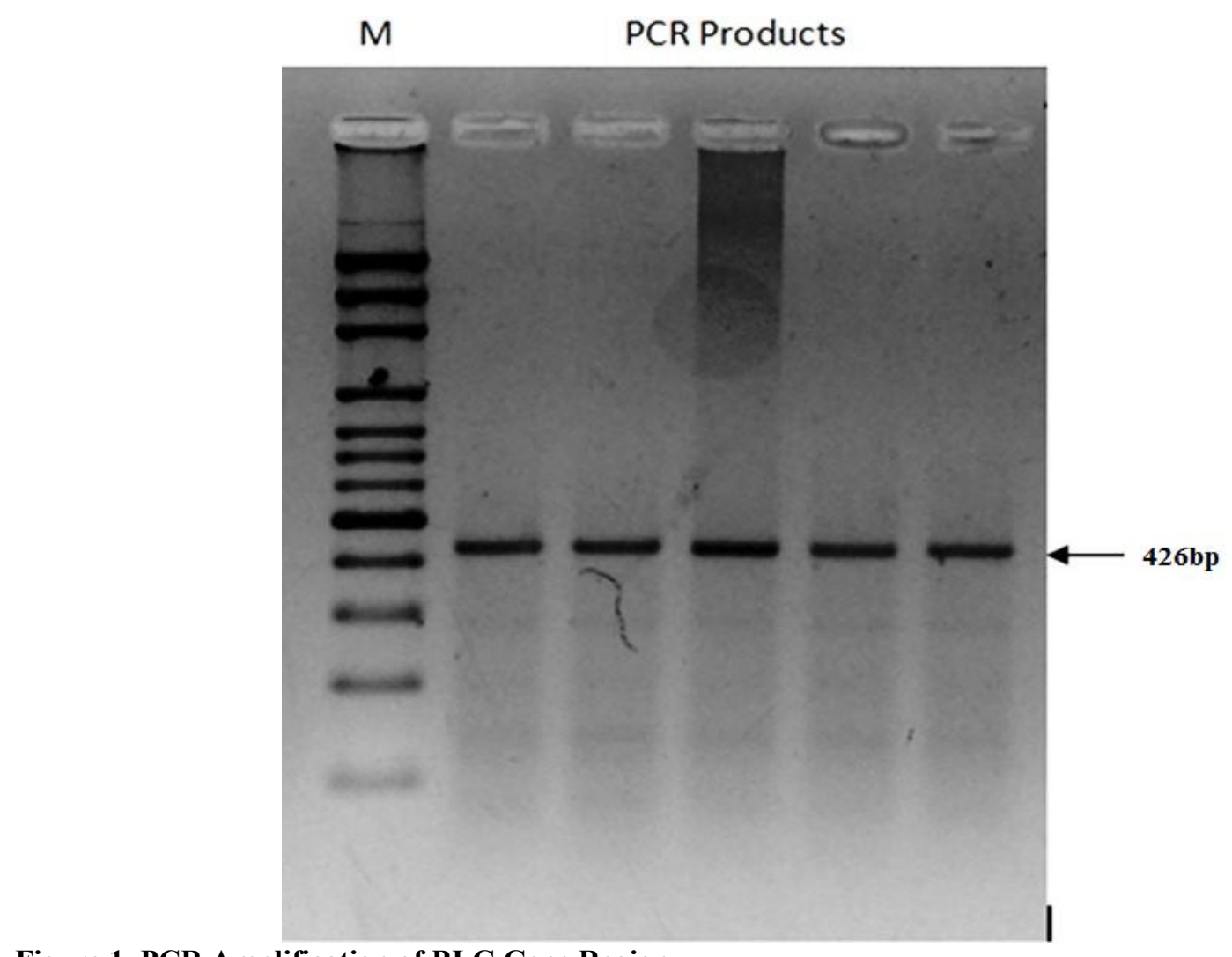

Figure 1. PCR Amplification of BLG Gene Region

$\mathrm{M}=100$ bp DNA ladder

PCR Products: All wells after M contain amplified PCR product 426bp in size

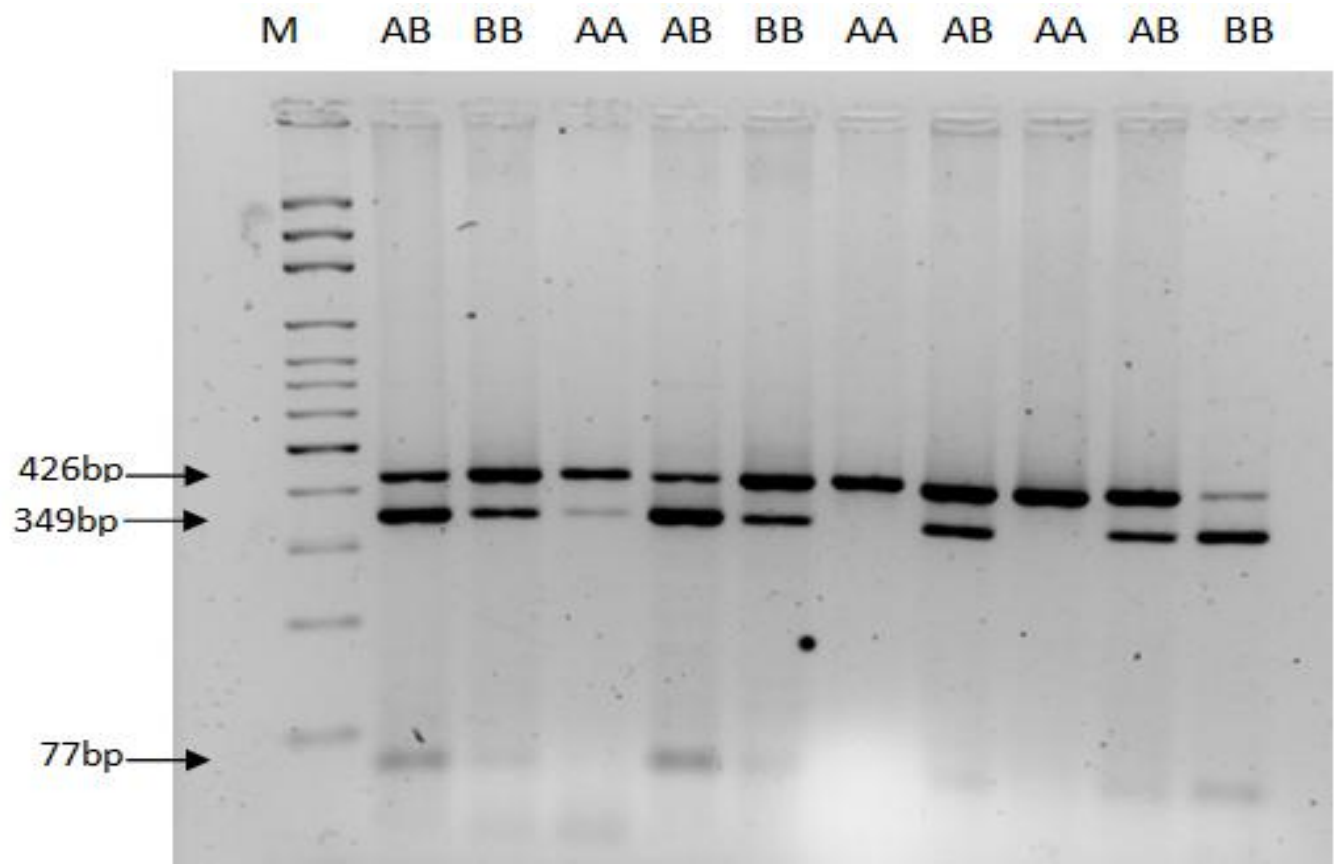

Figure 2. PCR-RFLP Profile for BLG Gene amplified region Showing A and B Isoforms

$\mathrm{M}=100 \mathrm{bp}$ DNA ladder 
Table 1. Comparison of milk constituents among Beetal and DDP goats

\begin{tabular}{lccc}
\hline \multirow{2}{*}{ Milk yield and Constituents } & Beetal & DDP & p-value \\
\cline { 2 - 3 } & $(\mathbf{N = 2 0 0 )}$ & Mean \pm SD & \\
\cline { 2 - 3 } & Mean \pm SD & $4.48 \pm 0.46$ & 0.02 \\
Milk Yield (L/Day) & $4.37 \pm 0.52$ & $2.46 \pm 0.99$ & 0.5 \\
Total Milk Protein (\%) & $2.52 \pm 0.93$ & $0.36 \pm 0.19$ & 1.0 \\
Whey Protein (\%) & $0.36 \pm 0.19$ & $2.10 \pm 0.83$ & 0.4 \\
Casein Protein (\%) & $2.16 \pm 0.77$ & $4.52 \pm 0.41$ & $<0.001$ \\
Total Milk Fat (\%) & $4.18 \pm 0.66$ & & \\
\hline
\end{tabular}

Table 2. BLG genotype and allele frequencies distribution in Beetal and DDP goats

\begin{tabular}{|c|c|c|c|c|c|c|c|}
\hline \multirow{2}{*}{ Goat Breeds } & \multicolumn{3}{|c|}{ Genotype Frequency } & \multirow{2}{*}{ p-value } & \multicolumn{2}{|c|}{ Allele Frequency } & \multirow{2}{*}{ p-value } \\
\hline & $\mathbf{A A}$ & $\mathbf{A B}$ & BB & & $\mathbf{A}$ & B & \\
\hline Beetal & 0.275 & 0.545 & 0.18 & 0.15 & 0.55 & 0.45 & 0.00072 \\
\hline DDP & 0.312 & 0.535 & 0.153 & 0.17 & 0.58 & 0.42 & $<.0 .0001$ \\
\hline
\end{tabular}

Table 3. BLG genotypes based comparison of milk constituents in Beetal and DDP goats

\begin{tabular}{|c|c|c|c|c|c|c|c|c|}
\hline \multirow{3}{*}{$\begin{array}{c}\text { Milk yield and } \\
\text { Constituents }\end{array}$} & \multirow{2}{*}{\multicolumn{3}{|c|}{$\frac{\text { Beetal }}{(\text { Means } \pm \text { SD) }}$}} & \multirow{3}{*}{$\begin{array}{c}\text { p- } \\
\text { value }\end{array}$} & \multirow{2}{*}{\multicolumn{3}{|c|}{$\frac{\text { DDP }}{(\text { Means } \pm \text { SD })}$}} & \multirow{3}{*}{$\begin{array}{r}\text { p- } \\
\text { value }\end{array}$} \\
\hline & & & & & & & & \\
\hline & $\mathbf{A A}$ & $\mathbf{A B}$ & BB & & $\overline{\mathbf{A A}}$ & $\mathbf{A B}$ & BB & \\
\hline Milk Yield (L/Day) & $4.35 \pm 0.44$ & $4.41 \pm 0.546$ & $4.25 \pm 0.511$ & 0.288 & $4.3 \pm 0.58$ & $4.4 \pm 0.48$ & $4.3 \pm 0.48$ & 0.288 \\
\hline Total Milk Protein (\%) & $2.24 \pm 0.97$ & $2.64 \pm 0.855$ & $2.56 \pm 0.98$ & 0.03 & $2.61 \pm 1.05$ & $2.52 \pm 0.93$ & $2.48 \pm 0.88$ & 0.850 \\
\hline Whey Protein (\%) & $0.31 \pm 0.18$ & $0.39 \pm 0.18$ & $0.36 \pm 0.2$ & 0.35 & $0.41 \pm 0.21$ & $0.37 \pm 0.19$ & $0.33 \pm 0.18$ & 0.175 \\
\hline Casein Protein $(\%)$ & $1.9 \pm 0.83$ & $2.25 \pm 0.71$ & $2.19 \pm 0.81$ & 0.04 & $2.2 \pm 0.86$ & $2.14 \pm 0.788$ & $2.1 \pm 0.77$ & 0.955 \\
\hline Total Milk Fat (\%) & $4.12 \pm 0.686$ & $4.2 \pm 0.67$ & $4.11 \pm 0.6$ & 0.491 & $4.13 \pm 0.70$ & $4.17 \pm 0.64$ & $4.19 \pm 0.68$ & 0.929 \\
\hline
\end{tabular}

Table 4. Association analysis of BLG B allele with milk constituents in Beetal and DDP goats.

\begin{tabular}{lcccccc}
\hline \multirow{2}{*}{ Milk yield and Constituents } & \multicolumn{2}{c}{ Beetal } & \multirow{2}{*}{ p-value } & \multicolumn{2}{c}{ DDP } & \multirow{2}{*}{ p-value } \\
\cline { 2 - 3 } & OR & CI (95\%) & & OR & CI (95\%) & \\
\hline Milk Yield (L/Day) & 1.48 & $0.85-2.5$ & 0.162 & 1.47 & $0.90-2.4$ & 0.122 \\
Total Milk Protein (\%) & 1.35 & $0.98-1.84$ & 0.61 & 0.7 & $0.722-1.24$ & 0.69 \\
Whey Protein (\%) & 4.8 & $1.06-21.62$ & 0.041 & 0.73 & $0.17-2.99$ & 0.66 \\
Casein Protein (\%) & 1.39 & $0.95-2.02$ & 0.8 & 0.94 & $0.68-1.30$ & 0.74 \\
Total Milk Fat (\%) & 1.32 & $0.86-2.02$ & 0.2 & 1.91 & $1.04-3.51$ & 0.037 \\
\hline
\end{tabular}

Acknowledgements: We are thankful to the government and private livestock farms for providing data and biological samples of animals. Funding for this research work was provided by Indigenous Scholarship [06311421-BM3-106], Higher Education Commission, Pakistan.

\section{REFERENCES}

Ballester, M., A. Sanchez and J. M. Folch (2005). Polymorphisms in the goat $\beta$-lactoglobulin gene. J. Dairy Res. 72(3): 379-384.

Barillet, F. (2007). Genetic improvement for dairy production in sheep and goats. Small Rumin. Res. 70(1): 60-75.
Bradford, M. M. (1976). A rapid and sensitive method for the quantitation of microgram quantities of protein utilizing the principle of protein-dye binding. Anal. Chem. 72(1-2): 248-254.

Cardona, S. J. C., H. C. Cadavid, J. D. Corrales, S. Munilla, R. J. Cantet and A. Rogberg-Muñoz (2016). Longitudinal data analysis of polymorphisms in the $\kappa$-casein and $\beta$ lactoglobulin genes shows differential effects along the trajectory of the lactation curve in tropical dairy goats. J. Dairy Res. 99(9): 72997307.

El-Hanafy, A., M. El-Saadani, M. Eissa, G. Maharem and Z. Khalifa (2010). Polymorphism of $\beta$-lacto globulin gene in Barki and Damascus and their 
cross bred goats in relation to milk yield. Biotechnol. Anim. Husb. 26(1-2): 1-12.

El-Shazly, S. A., M. M. Ahmed and S. A. Amer (2017). Genetic polymorphism in some milk protein genes and its impact on milk composition of Saudi Arabian goat breeds reared in Taif region. Rom. Biotechnol. Lett. 22(5): 12860.

El Hanafy, A., M. Qureshi, J. Sabir, M. Mutawakil, M. Ahmed, H. El Ashmaoui, H. Ramadan, M. Abou-Alsoud and M. Sadek (2015). Nucleotide sequencing and DNA polymorphism studies of beta-lactoglobulin gene in native Saudi goat breeds in relation to milk yield. Czech J. Anim. Sci 60(3): 132-138.

Folch, J., A. Coll and A. Sanchez (1994). Complete Sequence of the Caprine $\beta$-Lactoglobulin Gene1. J. Dairy Res. 77(12): 3493-3497.

Garg, N., S. K. Singh, P. K. Rout and A. Mandal (2009). Genetic polymorphism of milk proteins in Barbari goats. Tropical and Subtropical Agroecosystems 11(1).

GOP. (2019). Economic Survey of Pakistan 2018-19. Ministry of Finance. Govt of Pakistan., Islamabad.

Kleyn, D. H., J. M. Lynch, D. M. Barbano, M. J. Bloom and M. W. Mitchell (2001). Determination of fat in raw and processed milks by the Gerber method: collaborative study. J. AOAC. Int. 84(5): 1499-1508.

Korkmaz Ağaoğlu, Ö., B. Çınar Kul, B. Akyüz, Ö. Elmaz, M. Özçelik Metin, M. Saatcı and O. Ertuğrul (2012). Identification of $\beta$-lactoglobulin gene SacII polymorphism in Honamli, Hair and Saanen goat breeds reared in Burdur vicinity. Vet. Fak. Derg. 18(3): 385-388.

Kumar, A., P. K. Rout and R. Roy (2006). Polymorphism of $\beta$-lacto globulin gene in Indian goats and its effect on milk yield. J. Appl. Genet. 47(1): 4953.

Kumar, S., J. Gupta, N. Kumar, K. Dikshit, N. Navani, P. Jain and M. Nagarajan (2006). Genetic variation and relationships among eight Indian riverine buffalo breeds. Mol. Ecol. 15(3): 593-600.

Kusza, S., N. Sziszkosz, K. Nagy, A. Masala, S. Kukovics and J. András (2015). Preliminary result of a genetic polymorphism of $\beta$ lactoglobulin gene and the phylogenetic study of ten balkan and central european indigenous sheep breeds. Acta. Biochim. Pol. 21(48.75): 28.13.

Medrano, J. F. and E. Aguilar-Cordova (1990). Polymerase chain reaction amplification of bovine $\beta$-lactoglobulin genomic sequences and identification of genetic variants by RFLP analysis. Anal. Chem. 1(1): 73-77.

Mucha, S., R. Mrode, M. Coffey and J. Conington (2014). Estimation of genetic parameters for milk yield across lactations in mixed-breed dairy goats. J. Dairy Res. 97(4): 2455-2461.

Othman, O. E., S. A. El-Fiky, N. A. Hassan, E. R. Mahfouz and E. A. Balabel (2012). Genetic Polymorphism of Whey Protein Genes $\beta-L G$ and $\alpha$-LA in Three Egyptian Sheep Breeds. J. Appl. Biol. Sci. 6(3): 25-30.

Pena, R. N., A. Sanchez and J. M. Folch (2000). Characterization of genetic polymorphism in the goat $\beta$-lactoglobulin gene. J. Dairy Res. 67(2): 217-224.

Preaux, G., G. Braunitzer, B. Schrank and A. Stangl (1979). The Amino Acid Sequence of Goat BLactoglobulin. Hoppe-Seyler's Z. Physiol. Chem. 360(2): 1595-1604.

Ruprichová, L., M. Králová, I. Borkovcová, L. Vorlová and I. Bedán̆ová (2014). Determination of whey proteins in different types of milk. Acta. Vet. Brno 83(1): 67-72.

Sambrook, J. R. and D. Russell (2001). DW. 2001 Molecular cloning: a laboratory manual. Q. Rev. Biol. 76(3): 348-349.

Selvaggi, M., V. Laudadio, C. Dario and V. Tufarelli (2014). Major proteins in goat milk: an updated overview on genetic variability. Mol. Biol. Rep. 41(2): 1035-1048.

Yeang, H. Y., F. Yusof and L. Abdullah (1998). Protein purification for the Lowry assay: acid precipitation of proteins in the presence of sodium dodecyl sulfate and other biological detergents. Anal. Chem. 265(2): 381-384. 